\title{
THE CONTENT OF GLOBAL MARKETING
}

\author{
Branislav Djordjević \\ Emeritus, “Union” University, Belgrade, Serbia
}

\author{
(C) MESTE NGO
}

JEL category: M3, M31, 019, P45

\begin{abstract}
Consider the following proposition: We live in a global marketplace. US based Intel, the world's largest chip maker, competes with South Korea's Samsung. In the global cell phone market, Nokia (Finland), Ericsson (Sweden), Motorola (United States), and Samsung are key players. Appliances from Whirlpool and Electrolux compete for precious retail space with products manufactured and marketed by China's Haier Group and LG of South Korea.

Now consider a second proposition: We live in a world in which markets are local. In China, for example, Yum Brand's new East Dawning fast-food chain competes with local restaurants such as New Asia Snack. France's domestic film industry generates about 40 percent of local motion picture box office receipts; U.S. - made movies account for about 50 percent. For example, American auto industry giants General Motors and Ford Motor Company are locked in a competitive struggle with Toyota, Hyundai Motor Company, and other global Asian rivals as well as European companies such as Volkswagen.
\end{abstract}

Keywords: information revolution, globalization, global marketing, global strategy, multilateral agreement, development, leverage, management myopia

\section{INTRODUCTION}

The remarkable growth of the global economy over the past 65 years has been shaped by the dynamic interplay of various driving and restraining forces. During most of those decades, companies from different parts of the world in different industries achieved great successes by pursuing international, multinational, or global strategies. During the 1990s, changes in the business environment presented a number of

The address of the author:

Branislav Djordjević

麦=”'brankonis@live.com challenges to established ways of doing business. Today, despite calls for protectionism as a response to the economic crisis, global marketing continues to grow in importance. This is due to the fact that, even today, driving forces have more momentum than restraining forces. The forces affecting global integration are shown for in the Figure 1.

Regional economic agreements, converging market needs and wants, technology advances, pressure to cut costs, pressure to improve quality, improvements in communication and transportation technology, global economic growth, and opportunities for leverage all represent important driving forces; any industry 
subject to these forces is a candidate for globalization.

\section{MULTILATERAL AGREEMENTS}

TRADE

A number of multilateral trade agreements have accelerated the pace of global integration. NAFTA is already expanding trade among the United States, Canada, and Mexico. The General Agreement on Tariffs and Trade (GATT), which was ratified by more than 120 nations in 1994, has created the World Trade organization (WTO) to promote and protect free trade. In Europe, the expanding membership of the European Union is lowering boundaries to trade within the region. The creation of a single currency zone and the introduction of the euro are expected to expand European trade in the twenty-first century.

\section{CONVERGING MARKET NEEDS AND WANTS THE INFORMATION REVOLUTION}

A person studying markets around the world will discover cultural universals as differences. The common elements in human nature provide an underlying basis for the opportunity to create and serve global markets. The world is created deliberate. The majority of global markets does not arise spontaneously: Marketing efforts must create them. For example, no one needs soft drinks, and yet today in some countries per capita soft drink consumption exceeds the consumption of water. Marketing has driven this change in behavior, and today, the soft drink industry is a truly global one. Evidence is mounting that consumer needs and wants around the world are converging today as never before. This creates an opportunity for global marketing. Multinational companies pursuing strategies of product adaption run the risk of falling victim to global competitors that have recognized opportunities to serve global customers.

The information revolution - what Thomas L. Friedman refers to as the democratization of information - is one reason for the trend toward convergence. The revolution is fueled by a variety of technologies, products, and services, including satellite dishes, globe-spanning TV networks such as CNN and MTV, widespread access to broadband Internet, and Facebook, Twitter, YouTube, and other social media. Taken together, these communication tools mean that people in the remotest corners of the globe can compare their own lifestyles and standards of living with those in other countries.

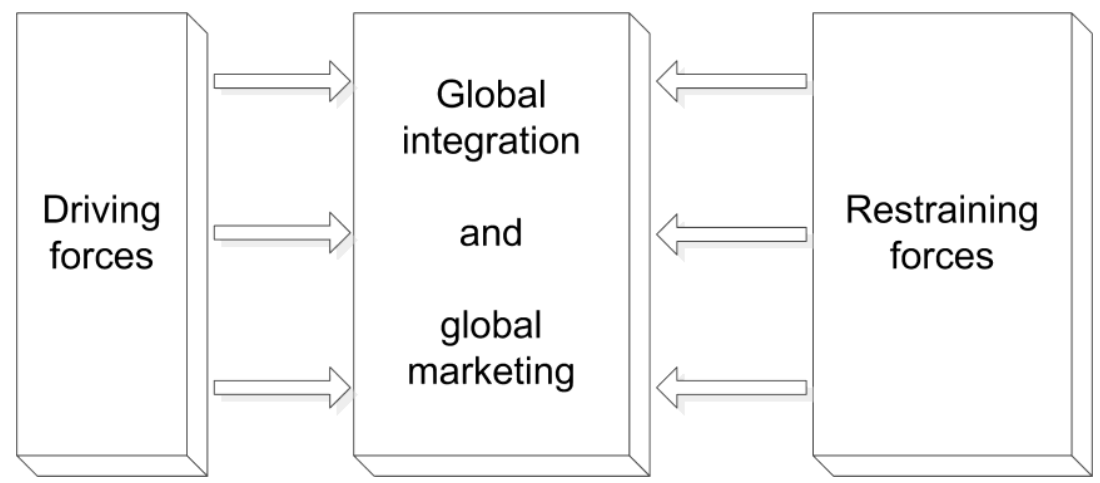

Fig. 1 Driving and restraining forces affecting global integration

In regional markets such as Europe and Asia, the increasing overlap of advertising across national boundaries and mobility of consumers have created opportunities for marketers to pursue pan-regional product positioning. The Internet is an even stronger driving force: When a company establishes a site on the Internet, it automatically becomes global. In addition, the Internet allows people everywhere in the world to reach out, buying and selling a virtually unlimited assortment of products and services.

\section{TRANSPORTATION COMMUNICATION IMPROVEMENTS}

AND

The time and cost barriers associated with distance have fallen tremendously over the past 
100 years. The jet airplane revolutionized communication by making it possible for people to travel around the world in less than 48 hours. Tourism enables people from many countries to see and experience the newest products sold abroad. In 1970, 75 million passengers traveled internationally. According to figures compiled by the International Air Transport Association, this figure was increased to nearly 540 million passengers in 2002. One essential characteristic of the effective global business is face-to-face communication among employees and between the company and its customers. Modern jet travel made such communication feasible. Today's information technology allows airline alliance partners such as United and Lufthansa to sell seats on each other's flight, thereby making it easier for travelers to get from point to point. Meanwhile, the cost of international telephone calls has fallen dramatically over the past several decades. That fact, plus the advent of new communication technologies such as e-mail, fax, video teleconferencing, $\mathrm{Wi}-\mathrm{Fi}$, and broadband Internet, means that managers, executive and customers can link up electronically from virtually any part of the world without traveling at all.

A similar revolution has occurred in transportation technology. The costs associated with physical distribution, both in terms of money and time, have been greatly reduced as well. The per-unit cost of shipping automobiles from Japan and Korea to the United States by specially designed auto-transport ships is less than the cost of overland shipping from Detroit to other U.S. coast. Another key innovation has been increased utilization of 20-and 40-foot metal containers that can be transferred from trucks to railroad cars to ships.

\section{PRODUCT COSTS}

The pressure for globalization is intense when new products require major investments and long periods of development time. The pharmaceuticals industry provides a striking illustration of this driving force. According to the Pharmaceutical Research and Manufacturers Association, the cost of developing a new drug in 1976 was $\$ 54$ million. Today, the process of developing a new drug and securing regulatory approval to market it can take 14 years. The average total cost of bringing a new drug to market is estimated to exceed \$400million. (DiMasi, Hansen, \& Grabowski, 2003) Such cost must be recovered in the global marketplace because no single national market is likely to be large enough to support investments of this size. Thus Pfizer, Merck, GlaxoSmithKline, Novartis, Bristol-Myers Squibb, Sanofi-Aventis, and other leading pharmaceutical companies have little choice but to engage in global marketing. As noted earlier, however, global marketing does not necessarily mean operating everywhere; in the pharmaceutical industry, for example, seven countries account for 75 percent of sales. As shown in 1-10, demand for pharmaceutical in Asia is expected to exhibit double-digit growth the next few years. In an effort to tap that opportunity and to reduce development costs, Novartis and its rivals are establishing research and development centers in China. (Zamiska, 2006)

\section{QUALITY}

Global marketing strategies can generate greater revenue and greater operating margins, which, in turn, support design and manufacturing quality. A global and a domestic company may each spend 5 percent of sales on $R \& D$, but the global company may have many times the total revenue of the domestic because it serves the world market. It is easy to understand how Nissan, Matsushita, Caterpillar, and other global companies have achieved world-class quality. Global companies "raise the bar" for all competitors in an industry. When a global company establishes a benchmark in quality, competitors must quickly make their own improvements and come up to par. For example, the U.S. auto manufacturers have seen their market share erode over the past four decades as Japanese manufacturers built reputations for quality and durability. Despite making great strides in quality, Detroit no faces a new threat: Sales, revenues, and profits have plunged in the wake of the economic crisis. Even before the crisis, the Japanese had invested heavily in hybrid vehicles that are increasingly popular with eco-conscious drivers. The runaway success of the Toyota Prius is a case in point. 


\section{WORLD ECONOMIC TRENDS}

Prior to the global economic crisis that began in 2008, economic growth had been a driving force in the expansion of the international economy and the growth of global marketing for three reasons.

First, economic growth in key developing countries creates market opportunities that provide a major incentive for companies to expand globally. Thanks to rising per capita incomes in India, China, and elsewhere, the growing ranks of middle-class consumers have more to spend than in the past. At the same time, slow growth in industrialized countries has compelled management to look abroad for opportunities in nations or regions with high rates of growth.

Second, economic growth has reduced resistance that might otherwise have developed in response to the entry of foreign firms into domestic economies. When a country such as China is experiencing rapid economic growth, policymakers are likely to look more favorably on outsiders. A growing country means growing markets; there is often plenty of opportunity for everyone. It is possible for a "foreign" company to enter a domestic economy and establish itself without threat the existence of local firms. The latter can ultimately be strengthened by the new competitive environment. Without economic growth, however, global enterprise may take business away from domestic ones. Domestic businesses are more likely to seek government intervention to protect their local positions if markets are not growing. Predictably, the current economic crisis creates as a result. In a recent book, Daniel Yergin and Joseph Stanislav described these trends as follows:

It is the greatest sale in the history of the world. Governments are getting out of business by disposing of what amounts to trillions of dollars of assets. Everything is going - from steel plants and phone companies and electric utilities to airlines and railroads to hotels, restaurants, and nightclubs. It is happening not only in the former Soviet Union, Eastern Europe, and China but also in Western Europe, Asia, Latin America, and Africa - and in the United States. (Yergin \& Stanislav, 1998)
For example, when a nation's telephone company is a state monopoly, the government can require it to buy equipment and services from national companies. An independent company that needs to maximize shareholder value has the freedom to seek vendors that offer the best overall value proposition, regardless of nationality. Privatization of telephone systems around the world creates significant opportunities for telecommunications equipment suppliers such as Sweden's Ericsson; Alcatel-Lucent, FrancoAmerican company; and Canada-based Nortel Networks. After years of growth, however, most of telecom suppliers are experiencing slower growth as customers cut spending in the face of the global recession. As this book went to press, Nortel Networks was on the brink of bankruptcy.

\section{LEVERAGE}

A global company possesses the unique opportunity to develop leverage. In the context of global marketing, leverage means some type of advantage that a company enjoys by virtue of the fact that it has experience in more than one country. Leverage allows a company to conserve resources when pursuing opportunities in new geographical markets. In other words, leverage enables a company to expend less time, less effort, or less money. Four important types of leverage are experience transfers, scale economies, resource utilization, and global strategy.

\subsection{Experience transfers}

A global company can leverage its experience in any market in the world. It can draw upon management practices, strategies, products, advertising appeals, or sales or promotional ideas that have been market-tested in one country or region and apply them in other comparable markets. For example, Whirlpool has considerable experiences in the United States dealing with powerful retail buyers such as Sears and Circuit City. The majority of European appliance retailers have plans to establish their own cross-border "power" retailing systems, as former Whirlpool CEO David Whitwam explained, "When power takes hold in Europe, we will be ready for it. The skills we've developed here are directly transferable." (Taylor \& Webber, 1997) 
Chevron is another example of the global company that gains leverage through experience transfers. As H.F. Iskander, general manager of Chevron's Kuwait office explains:

Chevron is pumping oil in different locations all over the world. There is no problem we have not confronted and solved somewhere. There isn't a rock we haven't drilled through. We centralize all that knowledge at our headquarters, analyze it, sort it out, and that enables us to solve any oildrilling problem anywhere. As a developing country you may have national oil company that has been pumping your own oil for twenty yours. But we tell them, "Look, you have twenty years of experience, but there's no diversity. It is just one year of knowledge twenty times over. "When you are operating in a multitude of countries, Like Chevron, you see a multitude of different problems and you have to come up with a multitude of solutions. You have to, or you won't be in business. All those solutions are then stored in Chevron's corporate memory. The key to our business now is to tap that memory, and bring out the solution that we used to solve a problem in Nigeria in order to solve the same problem in China or Kuwait. (Friedman, 2000)

\subsection{Scale economies}

The global company can take advantage of its greater manufacturing volume to obtain traditional scale advantage within a single factory. Also, finished products can be manufactured by combining components manufactured in scale-efficient plants in different countries. Japan's giant Matsushita Electric Company is a classic example of global marketing in action; it achieved scale economies by exporting VCRs, televisions, and other consumer electronics products throughout the world from world-scale factories in Japan. The importance of manufacturing scale has diminished somewhat, as companies implement flexible manufacturing techniques, and invest in factories outside the home country. However, scale economies were a cornerstone of Japanese success in the 1970s and 1980s.

Leverage from scale economies is not limited to manufacturing. Just as a domestic company can achieve economies in staffing by eliminating duplicate positions after an acquisition, a global company can achieve the same economies on a global scale by centralizing functional activities. The larger scale of the global company also creates opportunities to improve corporate staff competence and quality.

\subsection{Resource utilization}

A major strength of the global company is its ability to scan the entire world to identify people, money, and raw materials that will enable it to compete most effectively in world markets. For a global company, it is not problematic if the value of the "home" currency rises or falls dramatically because there really is no such thing as a home currency. The world is full of currencies, and a global company seeks financial resources on the best available terms. In turn, it uses them where is the greatest opportunity to serve a need at a profit.

\subsection{Resource strategy}

The global company's greatest single advantage can be its global strategy. A global strategy is built on information systems that scan the world business environment to identify opportunities, trends, threats, and resources. When opportunities are identified, the global company adheres to the three principles identified earlier: It leverages its skills and focuses its resources to create superior perceived value for customers and achieve competitive advantage. The global strategy is a design to create a wining offering on a global scale. This takes great discipline, much creativity, and constant effort. The reward is not just success, its survival. For example, French automaker Renault operated for many years as a regional company. During that time, its primary struggle was a two-way race with Peugeot Citroen for dominance in the French auto industry. However, in an industry dominated Toyota and other global competitors, a chairman Louis Schweitzer had no choice but to formulate a global strategy. Initiatives include acquiring a majority stake in Nissan Motor and Romania's Dacia. Schweitzer has also invested $\$ 1$ billion in a plant in Brazil and is spending hundreds of millions of dollars in South Korea. (Tagliabue, 2000) (Kirk \& Green, 2002)

A note of caution is in order: A global strategy is no guarantee of ongoing organizational success. Companies that cannot formulate or successfully 
implement a coherent global strategy may lose their independence. InBav's acquisition of Anheuser-Busch at the end of 2008 is a case in point. Some globalization strategies do not yield the expected results, as seen in the unraveling of the Daimler Chrysler merger and the failure of Deutsche Post's DHL unit to penetrate the U.S. domestic package delivery market.

The severe downturn in the business environment in the early years of the twenty-first century has wreaked havoc with strategic plans. This is proving true for established global firms as well as newcomers from emerging markets that only recently came to prominence on the world stage. For example, at Swiss-based $\mathrm{ABB}$ and Mexico's Cemex, the ambitious global visions of the respective chief executives were undermined by expensive strategic bets that did not pay off. (Millman, 2008) Although both companies survived, they are smaller, more focused entities than they were previously.

\subsection{Restraining forces}

Despite the impact of the driving forces identified previously, several restraining forces may slow a company's efforts to engage in global marketing. In addition to the market differences discussed earlier, important restraining forces include management myopia, organizational culture, national controls, and opposition to globalization. As we have noted, however, in today's world the driving forces predominate over the restraining forces. That is why the importance of global marketing is steadily growing.

\subsection{Management myopia and organizational culture}

In many cases, management simply ignores opportunities to pursue global marketing. A company that is "nearsighted" and ethnocentric will not expand geographically. Myopia is also a recipe for market disaster if headquarters attempts to dictate when it should listen. Global marketing does not work without a strong local team that can provide information about local market conditions. Executives at Parker Pen once attempted to implement a top-down marketing strategy that ignored experience gained by local market representatives. Costly market failures resulted in Parker's buyout managers of the former UK subsidiary.
Eventually, the Gillette Company acquired Parker.

In companies where subsidiary management "knows it all" there is no room for vision from the top. In companies where headquarters management is all-knowing, there is no room for local initiative or an in-depth knowledge of local needs and conditions. Executives and managers at successful global companies have learned how to integrate global vision and perspective with local market initiative and input. A striking theme emerged during interviews conducted by one of the authors with executives of successful global companies. That theme was the respect for local initiative and input by headquarters executive, and the corresponding respect for headquarters' vision by local executives.

\subsection{National controls}

Every country protects the commercial interests of local enterprises by maintaining control over market access and entry in both how-tech industries. Such control ranges from a monopoly controlling access to tobacco markets to national government control of broadcast, equipment, and data transmission markets. Today, tariff barriers have been largely removed in the high-income countries, thanks to the WTO, GATT, NAFTA, and other economic agreements. However, nontariff barriers (NTBs) are still very much in evidence. NTBs are non-monetary restrictions on cross-border trade such as the proposed "Buy American" provision in Washington's economic stimulus package, food safety rules, and other bureaucratic obstacles. NTB have the potential to make it difficult for companies to gain access to some individual country and regional markets.

\subsection{Opposition to globalization}

To many people around the world, globalization and global marketing represent a threat. The term globaphobia is sometimes used to describe an attitude of hostility toward trade agreements, global brands, or company policies that appear to result in hardship for some individuals or countries while benefiting others. Globaphobia manifests itself in various ways, including protests or violence directed at policymakers or well-known global companies. Oponents of globalization include labor unions, college and university students, national and international 
nongovernmental organizations (NGOs), and others.

In the United States, some people believe that globalization has depressed the wages of American worker and resulted in the loss bluecollar and white-collar jobs. Protectionist sentiment has increased in the wake of the ongoing economic crisis. In many developing countries, there is a growing suspicion that the world's advanced countries - starting with the United States - are reaping most of the rewards of free trade. As an unemployed miner in Bolivia put it, "Globalization is just another name for submission and domination. We've had to live with that here for 500 years and now we want to be our own masters." (Rohter, 2003)

\section{CONCLUSIONS}

The importance of global marketing today can be seen in the company rankings compiled by The Wall Street Journal, Fortune, Financial Times, and other publications. Whether ranked by revenues or other measure, most of the world's major corporations are active regionally or globally. The size of global markets for individual industries or product categories represent hundreds of billions of dollars in annual sales, other markets are much smaller. Whatever the size of the opportunity, successful industry competitors find that increasing revenues and profits means seeking markets outside the home country.
Company management can be classified in terms of its orientation toward the world: ethnocentric, polycentric, regiocentric, or geocentric. The terms reflect progressive levels of development or evolution. An ethnocentric orientation characterizes domestic and international companies; international companies pursue marketing opportunities outside the home market by extending various elements of the market. Marketing is an organizational function and a set of processes for creating, communicating, and delivering value to customers and for managing customer relationship in ways that benefit the organization and its stakeholders. A company that engages in global marketing focuses its resources on global market opportunities and threats. Successful global marketers such as Nestle, Coca-Cola, and Honda use familiar marketing mix elements - the four Ps - to create global marketing programs. Marketing, $R \& D$, manufacturing, and other activities comprise a firm's value chain. Firms configure these activities to create superior customer value on a global basis. The value equation (V-B/P) expresses the relationship between value and the marketing mix. Global companies also maintain strategic focus while relentlessly pursuing competitive advantage. The marketing mix, value chain, competitive advantage, and focus universal in their applicability, irrespective of whether a company does business only in the home country or has a presence in many markets around the world.

\section{WORKS CITED}

DiMasi, J. A., Hansen, R. W., \& Grabowski, H. (2003, 03). The Price of Innovation: New Estimate of Drug Development Cost. Journal of Health Economics, 22(2), 151.

Friedman, T. L. (2000). The Lexus and the Olive Tree. New York: Anchor Books.

Kirk, D., \& Green, P. S. (2002, 08 29). Renault Rolls the Dice on Two Auto Projects Abroad. The New York Times, WI, W7. Retrieved from http://www.nytimes.com/2002/08/29/business/renaultrolls-the-dice-on-two-auto-projects-abroad.html

Millman, J. (2008, 12 11). The Fallen: Lorenzo Zambrano: Hard Times for Cement Man. The Wall Street Journal, A1. Retrieved from http://online.wsj.com/news/articles/SB122894691555195919

Rohter, L. (2003, 10 17). Bolivia's Poor Proclaim Abiding Distrust of Globalization. The New York Times, A3. Retrieved from http://www.nytimes.com/2003/10/17/international/americas/17GLOB.html

Tagliabue, J. (2000, 07 02). Renault Pins Its Survival on a Global Gamble. The New York Times, section 3, pp. 1, 6.

Taylor, W. C., \& Webber, A. M. (1997). Going Global: Four Entrepreneurs Map the New World Marketplace. New York: Penguin Books. 
Yergin, D., \& Stanislav, J. (1998). The Commanding Heights. New York: Simon \& Shuster.

Zamiska, N. (2006, 11 11). Novartis to Establish Drug R\&D Center in China. The Wall Street Journal, A3.

Received for publication: $\quad 12.07 .2013$

Revision received: $\quad 12.11 .2013$

Accepted for publication: $\quad 12.12 .2013$

\section{How to cite this article?}

Style - APA Sixth Edition:

Djordjević, B. (2014, 01 15). The content of global marketing. (Z. Čekerevac, Ed.) FBIM Transactions, 2(1), 25-32. doi:10.12709/fbim.02.02.02.03

Stile - Chicago Fifteenth Edition

Djordjević, Branislav. "The content of global marketing." Edited by Zoran Čekerevac. FBIM Transactions (MESTE) 2, no. 1 (01 2014): 25-32.

Style - GOST Name Sort:

Djordjević Branislav The content of global marketing [Journal] = The content of global marketing // FBIM Transactions / ed. Čekerevac Zoran. - Belgrade : MESTE, 01 15, 2014. - 1 : Vol. 2. - pp. 25-32. - ISSN 2334-704X (Online); ISSN 2334-718X;

Style - Harvard Anglia:

Djordjević, B., 2014. The content of global marketing. FBIM Transactions, 15 01, 2(1), pp. 25-32.

Style - ISO 690 Numerical Reference:

The content of global marketing. Djordjević, Branislav. [ed.] Zoran Čekerevac. 1, Belgrade : MESTE, 01 15, 2014, FBIM Transactions, Vol. 2, pp. 25-32. ISSN 2334-704X (Online); ISSN 2334-718X. 